\title{
In-vitro Anti-Cancer Activity of Extracts Dracaen Cinnabari Balf. F Resin from Socotra Island in Yemen Republic Yasser Hussein Eissa Mohammed*
}

Department of Biological-Chemistry, Applied Science College, Hajja University, Yemen

\begin{abstract}
Plants have a long history of use in treatment of cancer, Since many years, plants were known to possess anticancer activities against different cancer cell lines. In this paper, we report a study based on anticancer properties of Dragon cinnabari resin. The resin of plant material was collected, shade dried and extracted with different solvents using soxhlet extraction procedure. In vitro anticancer activity is assayed with standard MTT colorimetric procedure against MCF-7 cell line. From the analysis it was found that Ether and Ethyl acetate of dragon cinnabari Balf. f showed nearly $50 \%$ MCF7 cell line inhibition at $100 \mu \mathrm{g} / \mathrm{ml}$ tested dose, whereas other extracts did not display much anticancer activities against MCF-7 breast cancer cell line. Based on the cytotoxicity studies against MCF-7 cell lines the ether and ethyl acetate extracts could be used as potential source for anticancer drugs.
\end{abstract}

Keywords: Dracaena cinnabari Blaf. F; Plant extract; Anticancer; MCF-7 cell line

\section{Introduction}

The plants can produce many metabolic compounds mainly during the secondary metabolites, plant extracts contain several compounds that have biological active which used as natural medicine [1]. Today herbal derivatives are considered as the basis for a large proportion of the medications in traditional and modern systems of medicine [2]. Bioactive compounds are normally accumulated as secondary metabolites in all plant cells but their concentration varies according to the plant parts. Resin is one of the highest accumulated plant part of such compounds and people are generally preferred it for therapeutic, purposes some of the active compounds inhibit the growth of disease causing microbes either singly or in combination [3]. Dragon's blood tree is a non-specific name for dark red resinous exudations from different plant species endemic to various regions around globe that belongs to four genera Dracaena spp. (Agavaceae), Croton spp. (Euphorbiaceae), Daemonorops spp. (Palmaceae) and Pterocarpus spp. (Fabaceae) have a long history of being used as a traditional medicine the world over. Medicinal use of dragon's blood dates back to the ancient Greeks, Romans, Chinese and Arabs [4]. However, Dracaena cinnabari Balf. f. (D. cinnabari) belongs to Agavaceae family, which is commonly known as Damm Al- akhwain in Yemen. It is endemic to the Socotra Island, Yemen. D. cinnabari resin has traditionally been used to treat diarrhea, wounds, fevers, ulcers, hemorrhage, control bleeding, fractures, and burns [5]. Plant has anti-microbial and cytotoxicity effect. Some constituents of Dracaena cinnabari have been identified: Dracophan, ametacyclophan, Cinnabaron, Abiflavonoids, Numerous phenolic compounds belong to the homoisoflavonoids and chalcons, Sterol, triterpenoids and a new biflavonoids were isolated from this plant. Despite its wide uses, little research has been done to know about its true source, quality control, bioactive compounds and clinical applications. Therefore, it is of great interest to carry out a screening of these plant parts in order to validate their use in folk medicine and to reveal the active principle by isolation and characterization of their constituents [5-7]. The systematic screening of them may result in the discovery of novel active compounds. Dracaena cinnabari Balf. $F$ resin was collected from Socotra Island (Yemen) on May 2014. Thus, in the present study attempts were made to investigate its anticancer activity of the resin extract of dragon cinnabari on MCF-7 cell line by standard MTT colorimetric procedure.

\section{Anticancer Activity}

There are many different anticancer herbs that have been used by different cultures throughout time for medicinal purposes, anticancer herbs come in many forms one of which is a type of thistle plants [810,11-19] Cancer is considered one of the most common causes of mortality worldwide. Progress made in cancer therapy has not been sufficient to a significantly lower annual death rate from most tumor types, and there is an urgent need for new strategies in cancer control [11]. For centuries, people have been using plants for their therapeutic values. Today 85000 plants have been documented for therapeutic use globally [12]. The World Health Organization (WHO) estimates that almost $75 \%$ of World's population has therapeutic experience with herbal drugs. Cancer is one of the most dangerous diseases in humans and presently there is a considerable scientific discovery of new anticancer agents from natural products [13]. The potential of using the natural products as anticancer drugs was recognized in 1950's by U.S. Natural Cancer Institute (NCI) since 1950 major contributions have taken for the discovery of naturally occurring anticancer drugs [14]. Dracaen cinnabari Balf. F. It was traditionally used to treat diarrhoea, dysentery, leucorrhoea, hemorrhoids, wounds, and infection during confinement, toothache and also it is used by the people in Yemene to cure diarrhea $[5,15]$. Biological activities such as anti-inflammatory and hepatoprotective activities were reported [16-19]. However, no work has been reported on the anticancer property of this plant. Keeping in view, the present study has been undertaken to investigate anticancer activity of the different extract of Dracaen cinnabari Balf. F against MCF-7 cells lines.

*Corresponding author: Yasser Hussein Eissa Mohammed, Department of Biological-Chemistry, Applied Science College, Hajja University, Yemen, Tel 00967733055949; E-mail: issayasser16@gmail.com

Received: May 25, 2016; Accepted: September 28, 2016; Published September 30, 2016

Citation: Mohammed YHE (2016) In-vitro Anti-Cancer Activity of Extracts Dracaen Cinnabari Balf. F Resin from Socotra Island in Yemen Republic. Biochem Anal Biochem 5: 296. doi: 10.4172/2161-1009.1000296

Copyright: (c) 2016 Mohammed YHE. This is an open-access article distributed under the terms of the Creative Commons Attribution License, which permits unrestricted use, distribution, and reproduction in any medium, provided the original author and source are credited. 


\section{Materials and Methods}

\section{Materials}

The MCF-7 cell line (from NCCS, Pune), Cells in appropriate medium: DMEM-High glucose (Himedia), Adjustable multichannel pipettes and a pipettor (from Thermo Scientific, USA), MTT Reagent ( $5 \mathrm{mg} / \mathrm{ml}$ ) (From Himedia),0.5DMSO (Himedia), D-PBS (Invitrogen), 96-well plate for culturing the cells (From Corning, USA), 96-well ELISA plate reader or spectrophotometer capable of measuring the absorbance (From Biotech), Inverted microscope, $37^{\circ} \mathrm{C}$ incubator with humidified atmosphere of $5 \% \mathrm{CO}_{2}$ (From Healforce), cytometry (From Biotech) [20].

\section{Assay controls}

(i) Medium control (medium without cells).

(ii) Negative control (medium with cells but without the experimental drug/compound).

(iii) Positive control (medium with cells treated with a known drug, Metformin; $5 \mathrm{mM}$ ).

\section{Collection of plant material}

Dragon's blood tree (D. cinnabari) resin was collected from Socotra Island (Yemen) On May 2014.

\section{Preparation of extracts}

The powdered resin was successively extracted by using $500 \mathrm{~g}$ from resin material and dissolved with different solvents upon the polarity from non-polar to polar of the solvents (Hexane, Benzene, Diethyl ether, Dichloromethane, Chloroform, Ethyl acetate, Acetone, Ethanol, Methanol, Water) by using Soxhlet apparatuses. The exaction process started from non-polar to polar are summarized in Table 1 . The extracts samples were kept at $0^{\circ} \mathrm{C}$ for further assays [7-19] (Table 1).

\section{MTT assay}

The amount of viable cells was determined by examining cell number with the 3-(4, 5-dimethylthiazol- 2-yl)-2, 5 -diphenyltetrazolium bromide (MTT, $5 \mathrm{mg} / \mathrm{ml}$ ) dye-reduction assay measuring mitochondrial respiratory function. The antiproliferation (cytotoxicity) of D. cinnabari extracts on MCF-7 was evaluated by the MTT assay. The monolayer cell culture was trypsinized and the cell count was adjusted, using DMEM containing $10 \%$ FBS, such that $200 \mu \mathrm{l}$ of suspension contains approximately 25,000 cells. To each well of the 96 well microtitre plate, $200 \mu \mathrm{l}$ of the diluted cell suspension (approximately 25,000 cells) was added. After $24 \mathrm{~h}$, when a partial monolayer was formed, the supernatant was aspirated and $200 \mu \mathrm{l}$ of

\begin{tabular}{|c|c|}
\hline Solvent & Resin \\
\hline Hexane & $12 \mathrm{gm}$ \\
\hline Benzene & $33.5 \mathrm{gm}$ \\
\hline Diethyl ether & $60 \mathrm{gm}$ \\
\hline Dichloromethane & $14.8 \mathrm{gm}$ \\
\hline Chloroform & $45 \mathrm{gm}$ \\
\hline Ethyl acetate & $120.5 \mathrm{gm}$ \\
\hline Acetone & $64 \mathrm{gm}$ \\
\hline Ethanol & $55 \mathrm{gm}$ \\
\hline Methanol & $88.2 \mathrm{gm}$ \\
\hline Water & $5 \mathrm{gm}$ \\
\hline Residue & $200 \mathrm{gm}$ \\
\hline
\end{tabular}

Table 1: Shows the yield of phytochemicals in the solvent extracts of $D$. cinnabari resin. different test concentrations of test drugs were added on to the partial monolayer in microtitre plate. The plate was then incubated at $37{ }^{\circ} \mathrm{C}$ for $24 \mathrm{~h}$ in $5 \% \mathrm{CO}_{2}$ atmosphere. After $24 \mathrm{~h}$, the plate was removed from the incubator and MTT reagent was added to a final concentration of $10 \%$ of total volume. The plate wrapped with aluminum foil to avoid exposure to light and incubated for $3 \mathrm{~h}$ at $37^{\circ} \mathrm{C}$ in $5 \% \mathrm{CO}_{2}$ atmosphere. The culture medium was aspirated without disturbing the monolayer. Then $100 \mu \mathrm{l}$ of solubilisation solution (DMSO) was added and the plate was gently shaken in a gyratory shaker to solubilize the formed formazan. The absorbance was measured using a microplate reader at a wavelength of $570 \mathrm{~nm}$. The percentage growth inhibition was calculated using the following formula and concentration of test drug needed to inhibit cell growth by $50 \%\left(\mathrm{IC}_{50}\right.$ ) values is generated from the dose-response curves for each cell line. The MTT assay can be used reliably to measure metabolic activity of cell cultures in vitro for the assessment of growth characteristics $\mathrm{IC}_{50}$-values and cell survival [20].

Cell lines and culturing: MCF-7 cells were cultured in DMEM HG (Himedia) in T-75 tissue culture flask (Corning) until they reached $70 \%$ confluence. The cells were then harvested and used for the evaluation of anti-cancer activity, these steps of cell lines culturing can be represented as following:

\section{Day 1: Cell seeding}

1. Calculate the number of cells and media required and make a cell suspension:

1 well $\rightarrow 25,000$ cells in $200 \mu \mathrm{l}$ media

'52' wells $\rightarrow(25,000 \times \mathrm{n})$ cells in $(200 \times \mathrm{n}) \mu \mathrm{l}$ media

Eg. 52 wells $\rightarrow(25000 \times 52)=1.3 \times 10^{6}$ cells in $(200 \times 52)=10400$ $\mu \mathrm{l}$ (or $10.4 \mathrm{ml}$ ) media

2 . Seed the cells by pipetting $200 \mu \mathrm{l}$ of cell suspension into each well (25,000 cells)

\section{Incubate at $37^{\circ} \mathrm{C}$ for 24 hours.}

\section{Day 2: Drug addition}

1. Make stock solution for the drug depending on the test concentrations required (Eg. $1 \mathrm{mg} / \mathrm{ml})$

2. Make test concentrations by serially diluting the stock $(5,25,50$, $75,100 \ldots . \mu \mathrm{g} / \mathrm{ml})$

Dilution factor $(\mathrm{DF})=[$ Stock conc. $] /[$ Test conc $]$

Vol. required from stock $=$ Total drug volume needed $/ \mathrm{DF}$

Eg. For stock of $1 \mathrm{mg} / \mathrm{ml}$

If test conc required is $50 \mu \mathrm{g} / \mathrm{ml}$ in a total of $500 \mu \mathrm{l}$ media

$\mathrm{DF}=1 \times 1000 \mu \mathrm{g} / \mathrm{ml} / 50 \mu \mathrm{g} / \mathrm{ml}=20$

Vol. required from stock $=500 \mu \mathrm{l} / 20=25 \mu \mathrm{l}$

So, Take $25 \mu \mathrm{l}$ of drug from stock $+475 \mu \mathrm{l}$ of media

3. Remove media from all the wells and add the respective drug concentrations to each well.

4. Incubate at $37^{\circ} \mathrm{C}$ for 24 hours.

Day 3: MTT addition and reading

1. Make required volume of media containing $10 \%$ MTT.

Eg. For 54 wells 
Total media required $=54 \times 200 \mu \mathrm{l}=10800 \mu \mathrm{l}($ or $10.8 \mathrm{ml})$

$10 \%$ of $10.8=1080 \mu$

So, $1080 \mu \mathrm{l} \mathrm{MTT}+9720 \mu \mathrm{l}$ media

2. Remove the media from all the wells and add $200 \mu \mathrm{l}$ MTT containing media to all the wells.

3. Incubate for 3 hours at $37^{\circ} \mathrm{C}$ in dark.

4. After the formazon crystals have formed remove media from all the wells and add $100 \mu \mathrm{l}$ of DMSO to all the wells and shake the plate to dissolve the formazon crystals.

5. Measure the absorbance in a microplate reader at $570 \mathrm{~nm}$ [18-23]

\section{LDH assay}

LDH assays can be achieved by evaluating $\mathrm{LDH}$ released into the media as a marker of dead cells or performing lysis LDH as an indication of remaining live cells. Apoptosis and necrosis are two most important forms of cell death observed in normal and disease pathologies. A key signature for necrotic cells is the permeabilization of plasma membrane. This plasma membrane leakage from necrotic cells causes the release of intracellular contents into extracellular environment. In this experiment we detect the release of the enzyme Lactate dehydrogenase (LDH). LDH is a soluble cytoplasmic enzyme that is present in almost all cells and is released into extracellular space when the plasma membrane is damaged. The cells are fixed and stained with fluorescence tagged antibodies specific to this particular enzyme which is then measured by flow cytometry. Therefore, necrotic cells show decreased fluorescence intensity when compared to nonnecrotic/healthy cells.

\section{Materials}

$70 \%$ Ethanol $\left(-20^{\circ} \mathrm{C}\right)$, Trypsin-EDTA solution, $1 \mathrm{x}$ PBS, $0.5 \%$ bovine serum albumin (BSA) in 1X phosphate-buffered saline (PBS), Mouse Anti-Lactate Dehydrogenase antibody (Abcam Catalog no. ab55433), Goat Anti-Mouse Ig FITC (BD Biosciences Catalog No. 349031).

\section{Equipment}

1. Centrifuge.

2. Pipettes. You will need one in the range of 2-10 $\mu \mathrm{l}$, one in the range of 10-100 $\mu \mathrm{l}$, and another ranging from $100-1000 \mu \mathrm{l}$.

3. Vortex mixer. You could mix by tapping or shaking the tubes, but a mixer will give much more reproducible results in most cases.

$4.12 \times 75 \mathrm{~mm}$ polystyrene tubes.

5. Ice bucket with cover. Generally, cells are more stable and tolerate insult better when they're cold. The cover keeps light out, which could bleach the fluorochromes.

\section{Flow cytometer.}

\section{Procedure}

1. Culture cells in a 6-well plate at a density of $1 \times 10^{5}$ cells $/ 2 \mathrm{ml}$ and incubate in a $\mathrm{CO}_{2}$ incubator overnight at $37^{\circ} \mathrm{C}$ for 24 hours.

2. Aspirate the spent medium and treat the cells with required concentration of experimental compounds and control in $2 \mathrm{ml}$ of culture medium and incubate the cells for 24 hours.

3. At the end of the treatment, remove the medium from all the wells and give a PBS wash. Remove the PBS and add $200 \mu$ of trypsinEDTA solution and incubate at $37^{\circ} \mathrm{C}$ for $3-4$, minutes. Add $2 \mathrm{ml}$ culture medium and harvest the cells directly into $12 \times 75 \mathrm{~mm}$ polystyrene tubes.

4. Centrifuge the tubes for five minutes at $300 \times \mathrm{g}$ at $25^{\circ} \mathrm{C}$. Carefully decant the supernatant.

5. Wash twice with $1 \mathrm{ml}$ PBS. Decant the PBS completely and blot lip dry.

6. Add $1 \mathrm{ml}$ chilled $70 \%$ ethanol to the pellet while continuously vortexing and keep the tubes at $4^{\circ} \mathrm{C}$ for 15 minutes. Centrifuge the tubes for five minutes at $300 \mathrm{xg}$ at $4^{\circ} \mathrm{C}$. Carefully decant the supernatant.

7. Wash with $1 \mathrm{ml}$ PBS. Add $1 \mathrm{ml}$ of $0.5 \%$ BSA in $1 \mathrm{X}$ phosphatebuffered saline (PBS) and incubate for 15 minutes. Centrifuge the tubes for five minutes at $300 \mathrm{xg}$ at $4^{\circ} \mathrm{C}$. Carefully decant the supernatant.

8. Add $100 \mu \mathrm{l}$ of $0.5 \%$ BSA in $1 \mathrm{X}$ phosphate-buffered saline (PBS) containing the Primary Antibody (Mouse Anti-Lactate Dehydrogenase antibody) at 1:100 dilution. Mix thoroughly and incubate for 30 minutes in the dark at room temperature $\left(20^{\circ} \mathrm{C}\right.$ to $\left.25^{\circ} \mathrm{C}\right)$. (PBS)

9. Wash with $1 \mathrm{ml}$ of $0.5 \% \mathrm{BSA}$ in $1 \mathrm{X}$ phosphate-buffered saline

10. Add $100 \mu$ of $0.5 \%$ BSA in $1 X$ phosphate-buffered saline (PBS) containing the Secondary Antibody (Goat Anti-Mouse Ig FITC) at 4:100 dilution. Mix thoroughly and incubate for 30 minutes in the dark at room temperature $\left(20^{\circ} \mathrm{C}\right.$ to $\left.25^{\circ} \mathrm{C}\right) .11$. Wash with $1 \mathrm{ml} \mathrm{PBS}$. Add 0.5 $\mathrm{ml}$ of PBS, mix thoroughly, and analyze [22-25]

\section{Results}

The results obtained from the MTT assay are as follows.

Table 2, Figures 1 and 2.

Table 3, Figures 3 and 4 .

Table 4, Figures 5 and 6 .

Table 5, Figures 7 and 8 .

\begin{tabular}{|c|c|c|c|c|c|c|c|c|}
\hline \multicolumn{9}{|c|}{ Concentration Unit: $\mu \mathrm{g} / \mathrm{ml}$} \\
\hline & Blank & Untreated & Metformin (5 mM) & 5 & 25 & 50 & 75 & 100 \\
\hline Reading 1 & 0.007 & 0.747 & 0.331 & 0.744 & 0.433 & 0.35 & 0.194 & 0.211 \\
\hline Reading 2 & 0.016 & 0.802 & 0.369 & 0.767 & 0.443 & 0.259 & 0.253 & 0.15 \\
\hline Mean & 0.0115 & 0.7745 & 0.35 & 0.7555 & 0.438 & 0.3045 & 0.2235 & 0.1805 \\
\hline Mean OD-Mean B & NA & 0.763 & 0.3385 & 0.744 & 0.4265 & 0.293 & 0.212 & 0.169 \\
\hline SD & & 0.016263456 & 0.007071068 & 0.0070711 & 0.007071 & 0.064347 & 0.041719 & 0.043134 \\
\hline Standard error & & 0.011501737 & 0.005000755 & 0.0050008 & 0.005001 & 0.045507 & 0.029504 & 0.030505 \\
\hline Viability \% & NA & 100 & 44.36435125 & 97.50983 & 55.89777 & 38.40105 & 27.78506 & 22.14941 \\
\hline
\end{tabular}

Table 2: The percentage viability of the cells obtained from the cytotoxicity studies at IC50 $=48.117 \mu \mathrm{g} / \mathrm{ml}$ 


\section{Ether extract vs MCF-7 cells}

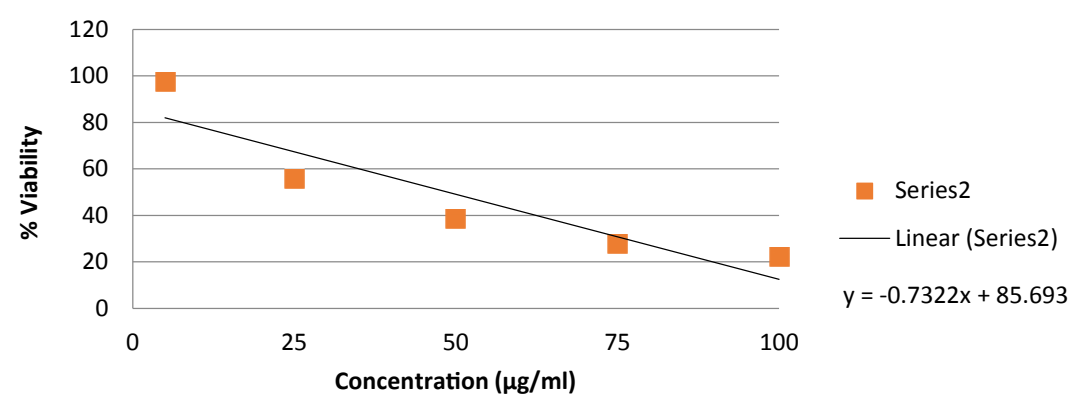

Figure 1: Ether extract vs. MCF-7 cells.

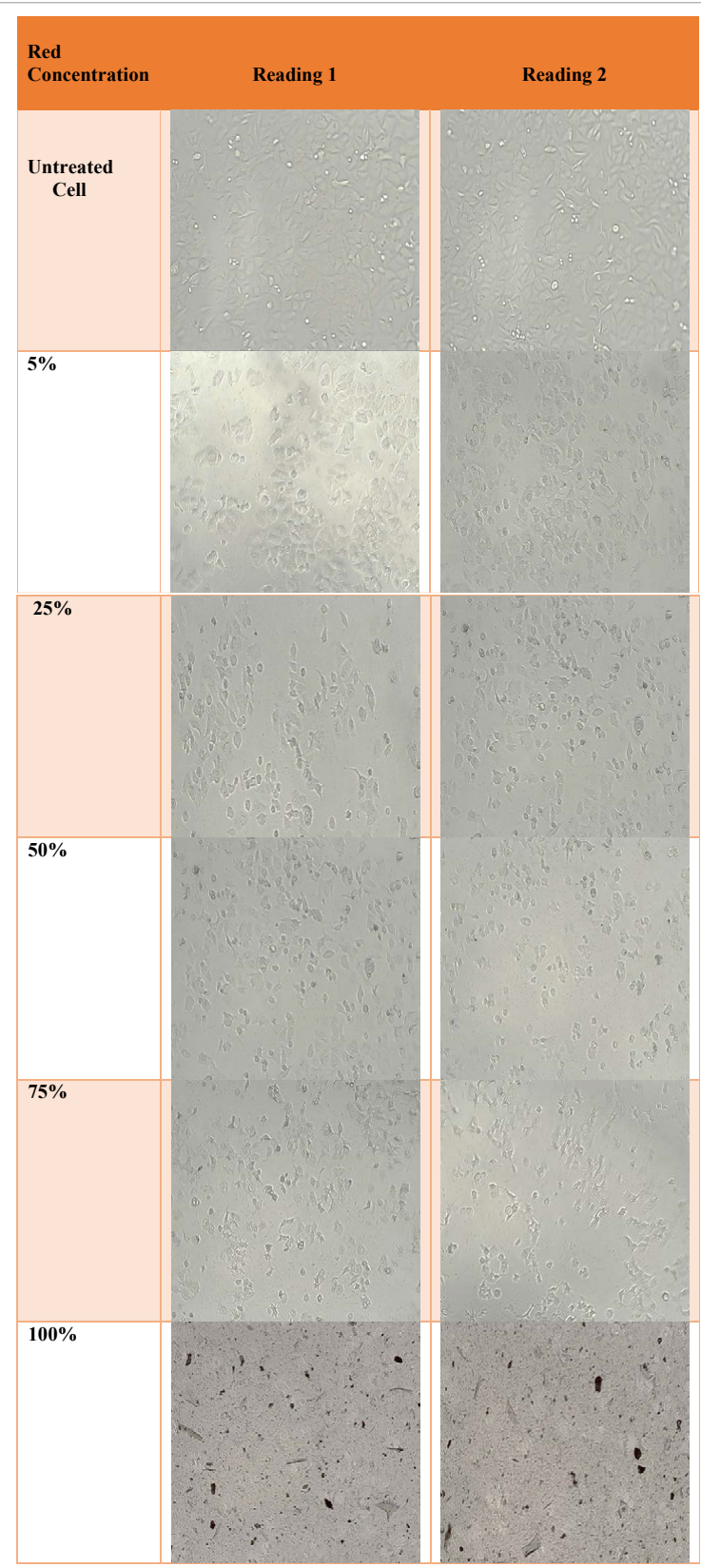

Figure 2: The cytotoxicity studies revealed that the half maximal inhibitory concentration (IC50) for the ether extract is $48.117 \mu \mathrm{g} / \mathrm{ml}$. 
Citation: Mohammed YHE (2016) In-vitro Anti-Cancer Activity of Extracts Dracaen Cinnabari Balf. F Resin from Socotra Island in Yemen Republic. Biochem Anal Biochem 5: 296. doi: 10.4172/2161-1009.1000296

Page 5 of 17

\begin{tabular}{|c|c|c|c|c|c|c|c|c|}
\hline \multicolumn{9}{|c|}{ Concentration Unit: $\mu \mathrm{g} / \mathrm{ml}$} \\
\hline & Blank & Untreated & Metformin (5 mM) & 5 & 25 & 50 & 75 & 100 \\
\hline Reading 1 & 0.007 & 0.747 & 0.331 & 0.587 & 0.508 & 0.423 & 0.249 & 0.206 \\
\hline Reading 2 & 0.016 & 0.802 & 0.369 & 0.541 & 0.515 & 0.378 & 0.285 & 0.249 \\
\hline Mean & 0.0115 & 0.7745 & 0.35 & 0.564 & 0.5115 & 0.4005 & 0.267 & 0.2275 \\
\hline Mean OD-Mean B & NA & 0.763 & 0.3385 & 0.5525 & 0.5 & 0.389 & 0.2555 & 0.216 \\
\hline SD & & 0.032526912 & 0.004949747 & 0.0049497 & 0.00495 & 0.03182 & 0.025456 & 0.030406 \\
\hline Standard Error & & 0.023003474 & 0.003500529 & 0.0035005 & 0.003501 & 0.022503 & 0.018003 & 0.021503 \\
\hline Viability \% & NA & 100 & 44.36435125 & 72.411533 & 65.5308 & 50.98296 & 33.48624 & 28.30931 \\
\hline
\end{tabular}

Table 3: The percentage viability of the cells obtained from the cytotoxicity studies at IC50 = 50.692 $\mu \mathrm{g} / \mathrm{ml}$.

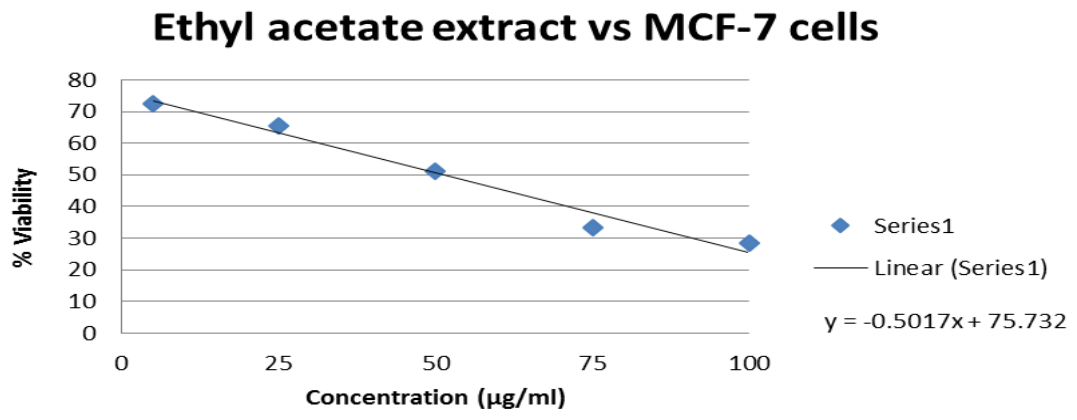

Figure 3: Ethyl acetate vs. MCF-7 cells.

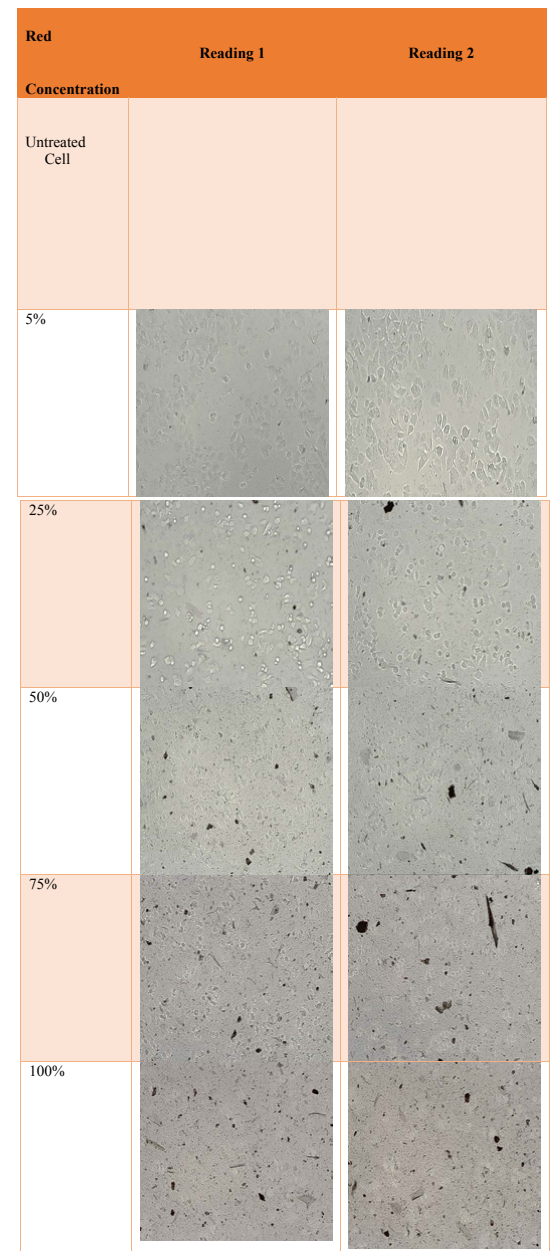

Figure 4: The cytotoxicity studies revealed that the most half maximal inhibitory concentration (IC50) for the Ethyl acetate extract is $50.692 \mu \mathrm{g} / \mathrm{ml}$. 
Citation: Mohammed YHE (2016) In-vitro Anti-Cancer Activity of Extracts Dracaen Cinnabari Balf. F Resin from Socotra Island in Yemen Republic. Biochem Anal Biochem 5: 296. doi: 10.4172/2161-1009.1000296

Page 6 of 17

\begin{tabular}{|c|c|c|c|c|c|c|c|c|}
\hline \multicolumn{9}{|c|}{ Concentration Unit: $\mu \mathrm{g} / \mathrm{ml}$} \\
\hline & Blank & Untreated & Metformin (5 mM) & 5 & 25 & 50 & 75 & 100 \\
\hline Reading 1 & 0.007 & 0.747 & 0.331 & 0.761 & 0.614 & 0.497 & 0.498 & 0.367 \\
\hline Reading 2 & 0.016 & 0.802 & 0.369 & 0.733 & 0.65 & 0.525 & 0.433 & 0.4 \\
\hline Mean & 0.0115 & 0.7745 & 0.35 & 0.747 & 0.632 & 0.511 & 0.4655 & 0.3835 \\
\hline Mean OD-Mean B & NA & 0.763 & 0.3385 & 0.7355 & 0.6205 & 0.4995 & 0.454 & 0.372 \\
\hline SD & & 0.01979899 & 0.025455844 & 0.0254558 & 0.025456 & 0.019799 & 0.045962 & 0.023335 \\
\hline Standard error & & 0.014002114 & 0.018002719 & 0.0180027 & 0.018003 & 0.014002 & 0.032505 & 0.016502 \\
\hline Viability \% & NA & 100 & 44.36435125 & 96.395806 & 81.32372 & 65.46527 & 59.50197 & 48.75491 \\
\hline
\end{tabular}

Table 4: The percentage viability of the cells obtained from the cytotoxicity studies at IC50 = 93.1136 $\mu \mathrm{g} / \mathrm{ml}$.

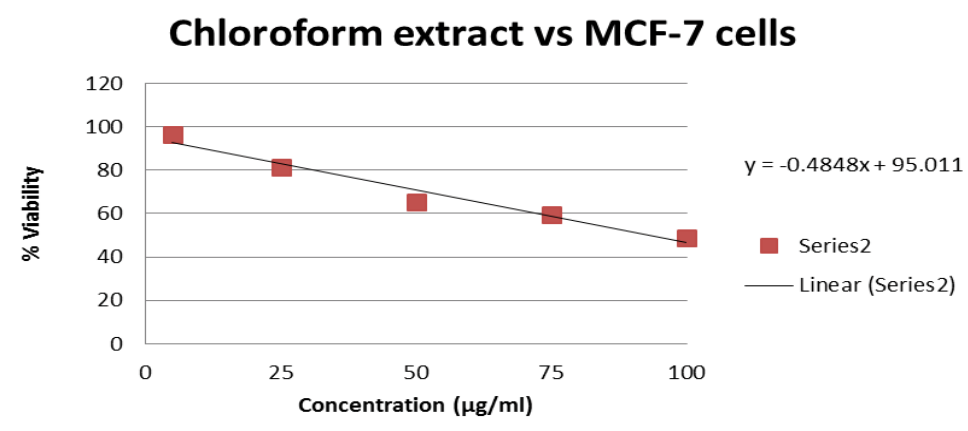

Figure 5: Chloroform vs. MCF-7 cells.

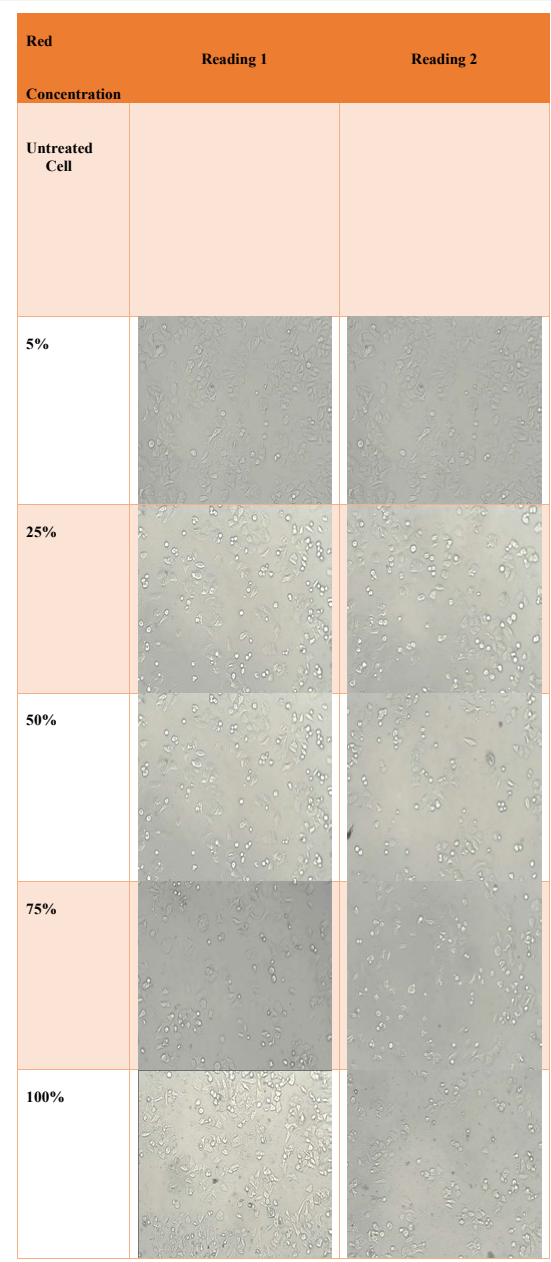

Figure 6: The cytotoxicity studies revealed that the minimum inhibitory concentration (IC50) for the Chloroform extract is $93.1136 \mu \mathrm{g} / \mathrm{ml}$. 
Citation: Mohammed YHE (2016) In-vitro Anti-Cancer Activity of Extracts Dracaen Cinnabari Balf. F Resin from Socotra Island in Yemen Republic. Biochem Anal Biochem 5: 296. doi: 10.4172/2161-1009.1000296

Page 7 of 17

\begin{tabular}{|c|c|c|c|c|c|c|c|c|}
\hline \multicolumn{9}{|c|}{ Concentration Unit: $\mu \mathrm{g} / \mathrm{ml}$} \\
\hline & Blank & Untreated & Metformin (5mM) & 5 & 25 & 50 & 75 & 100 \\
\hline Reading 1 & 0.007 & 0.747 & 0.331 & 0.654 & 0.675 & 0.602 & 0.561 & 0.414 \\
\hline Reading 2 & 0.016 & 0.802 & 0.369 & 0.752 & 0.726 & 0.619 & 0.512 & 0.404 \\
\hline Mean & 0.0115 & 0.7745 & 0.35 & 0.703 & 0.7005 & 0.6105 & 0.5365 & 0.409 \\
\hline Mean OD-Mean B & NA & 0.763 & 0.3385 & 0.6915 & 0.689 & 0.599 & 0.525 & 0.3975 \\
\hline SD & & 0.069296465 & 0.036062446 & 0.0360624 & 0.036062 & 0.012021 & 0.034648 & 0.007071 \\
\hline Standard error & & 0.049007401 & 0.025503851 & 0.0255039 & 0.025504 & 0.008501 & 0.024504 & 0.005001 \\
\hline Viability $\%$ & NA & 100 & 44.36435125 & 90.629096 & 90.30144 & 78.5059 & 68.80734 & 52.09699 \\
\hline
\end{tabular}

Table 5: The percentage viability of the cells obtained from the cytotoxicity studies at IC50 = $115.218 \mu \mathrm{g} / \mathrm{ml}$.

\section{Benzyle extract Vs MCF-7 cells}

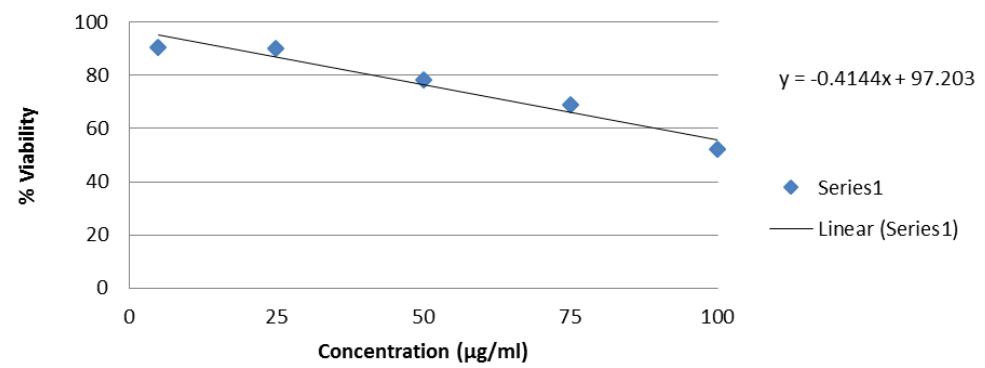

Figure 7: Benzene vs. MCF-7 cells.

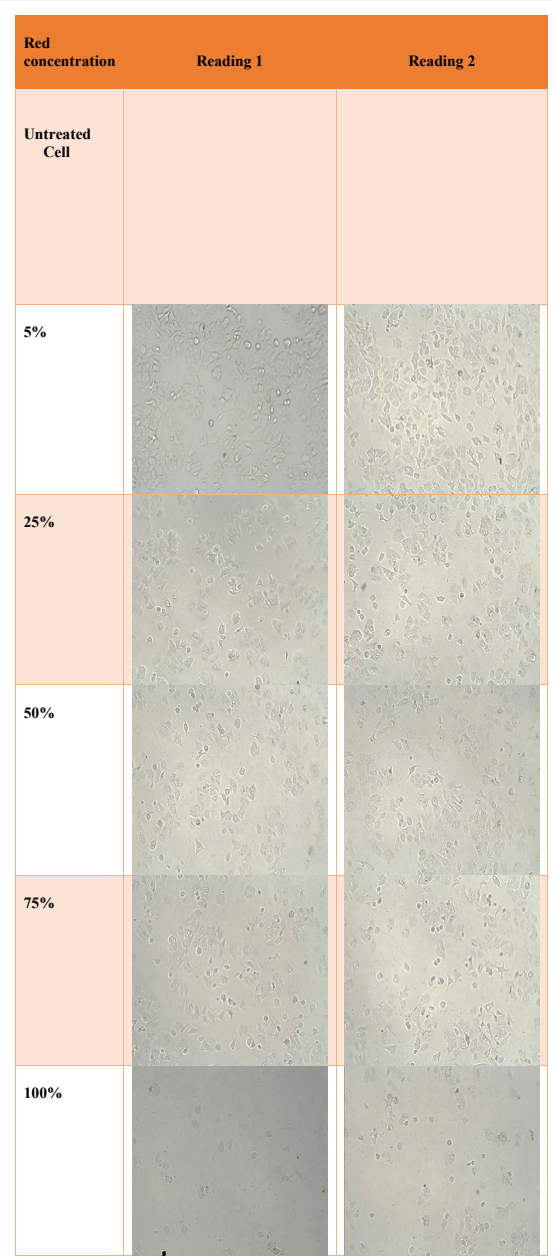

Figure 8: The cytotoxicity studies revealed that the half minimum inhibitory concentration (IC50) for the benzene extract is $115.218 \mu \mathrm{g} / \mathrm{ml}$ which is less than chloroform extract. 
Citation: Mohammed YHE (2016) In-vitro Anti-Cancer Activity of Extracts Dracaen Cinnabari Balf. F Resin from Socotra Island in Yemen Republic. Biochem Anal Biochem 5: 296. doi: 10.4172/2161-1009.1000296

Page 8 of 17

\begin{tabular}{|c|c|c|c|c|c|c|c|c|}
\hline \multicolumn{9}{|c|}{ Concentration Unit: $\mu \mathrm{g} / \mathrm{ml}$} \\
\hline & Blank & Untreated & Metformin (5 mM) & 5 & 25 & 50 & 75 & 100 \\
\hline Reading 1 & 0.007 & 0.747 & 0.331 & 0.706 & 0.703 & 0.532 & 0.504 & 0.582 \\
\hline Reading 2 & 0.016 & 0.802 & 0.369 & 0.742 & 0.71 & 0.632 & 0.584 & 0.635 \\
\hline Mean & 0.0115 & 0.7745 & 0.35 & 0.724 & 0.7065 & 0.582 & 0.544 & 0.6085 \\
\hline Mean OD-Mean B & NA & 0.763 & 0.3385 & 0.7125 & 0.695 & 0.5705 & 0.5325 & 0.597 \\
\hline SD & & 0.025455844 & 0.004949747 & 0.0049497 & 0.00495 & 0.070711 & 0.056569 & 0.037477 \\
\hline Standard error & & 0.018002719 & 0.003500529 & 0.0035005 & 0.003501 & 0.050008 & 0.040006 & 0.026504 \\
\hline Viability $\%$ & NA & 100 & 44.36435125 & 93.381389 & 91.08781 & 74.77064 & 69.7903 & 78.24377 \\
\hline
\end{tabular}

Table 6: The percentage viability of the cells obtained from the cytotoxicity studies at IC50=200.8177 $\mu \mathrm{g} / \mathrm{ml}$.

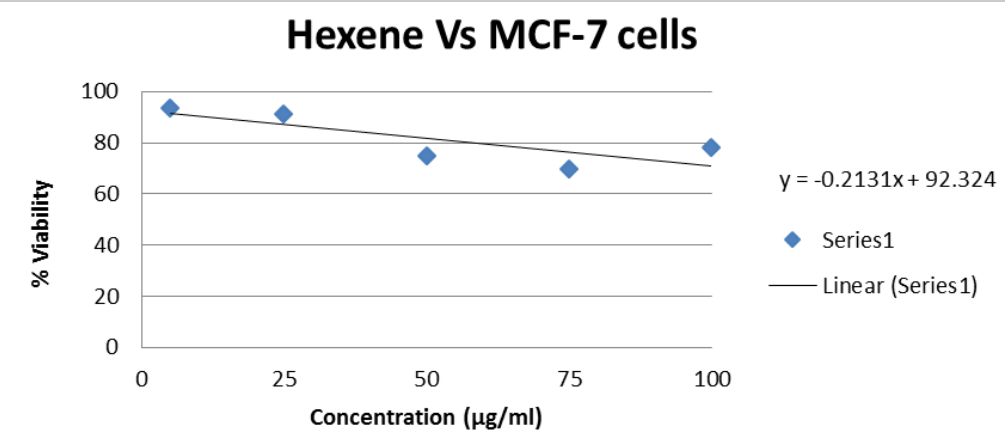

Figure 9: Hexane vs. MCF-7 cells.

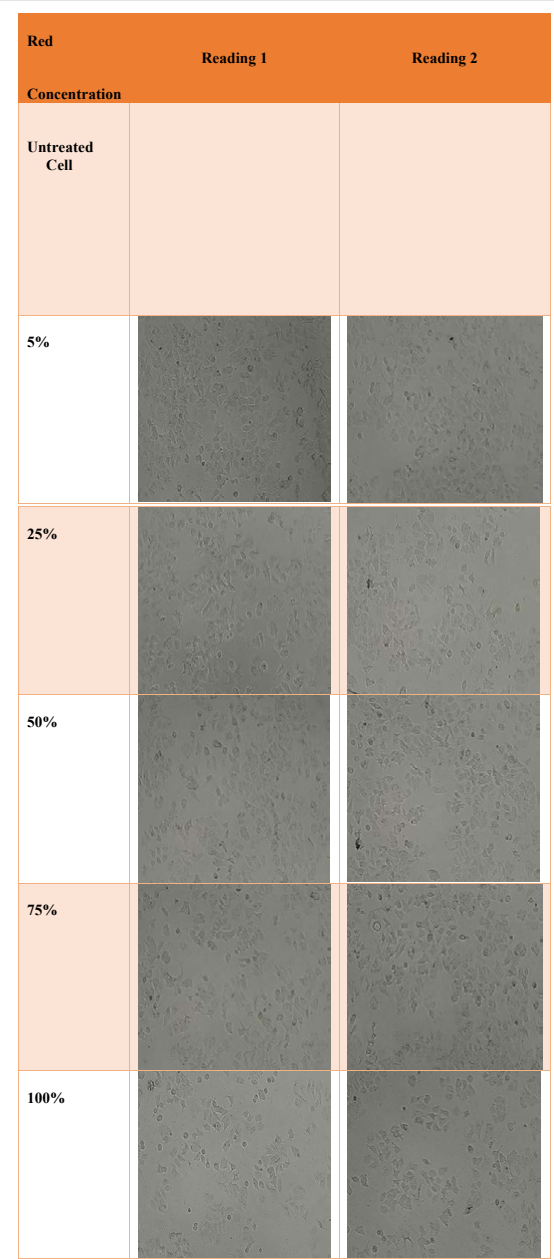

Figure 10: The cytotoxicity studies revealed that the minimum inhibitory concentration (IC50) for the hexane extract is $93.1136 \mu \mathrm{g} / \mathrm{ml}$ which is the least extract. 


\section{Untreated Positive Control}
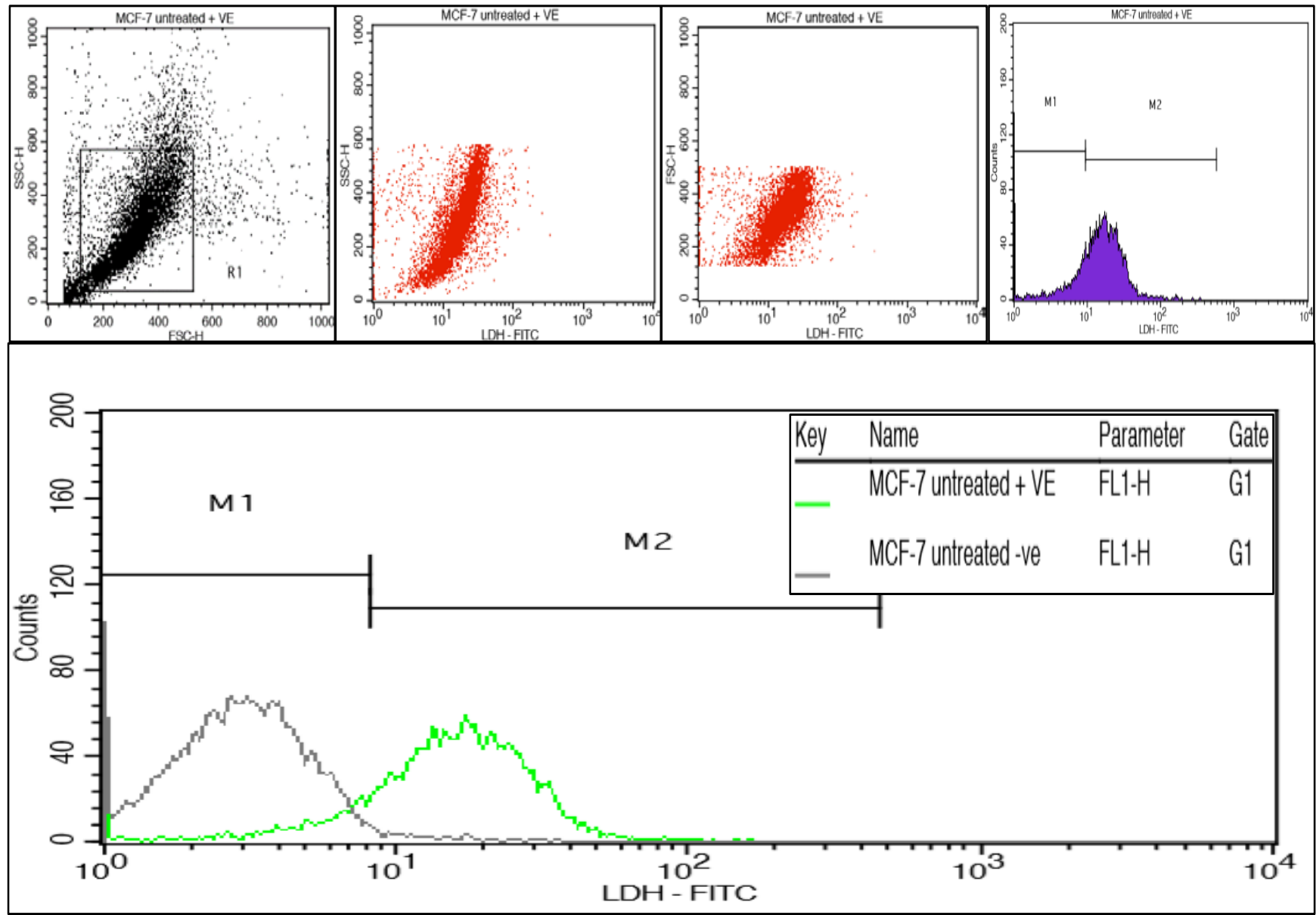

Histogram Statistics

File: MCF-7 untreated + VE

Sample ID: MCF-7 untreated + VE

Tube: Untitled

Acquisition Date: 24-Jun-15

Gated Events: 7573

X Parameter: LDH - FITC (Log)
Log Data Units: Linear Values

Patient ID:

Panel: Untitled Acquisition Tube List

Gate: G1

Total Events: 9420

\begin{tabular}{rrrrrrrrrr} 
Marker & Left, Right & Events & \% Gated & \% Total & Mean & Geo Mean & CV & Median & Peak Ch \\
\hline All & 1, 9910 & 7559 & 100.00 & 80.24 & 17.87 & 14.39 & 72.59 & 15.82 & 1 \\
M1 & $1, \quad 8$ & 1152 & 15.24 & 12.23 & 4.93 & 4.11 & 47.47 & 5.38 & 1 \\
M2 & 8, 445 & 6448 & 85.30 & 68.45 & 20.11 & 17.94 & 63.25 & 17.47 & 17
\end{tabular}

Figure 11: Untreated LDH FITC stained cells appeared in the M2 region (85.3\%) as LDH positive cells with increased FITC fluorescence intensity. 


\section{Unstained Negative Control}
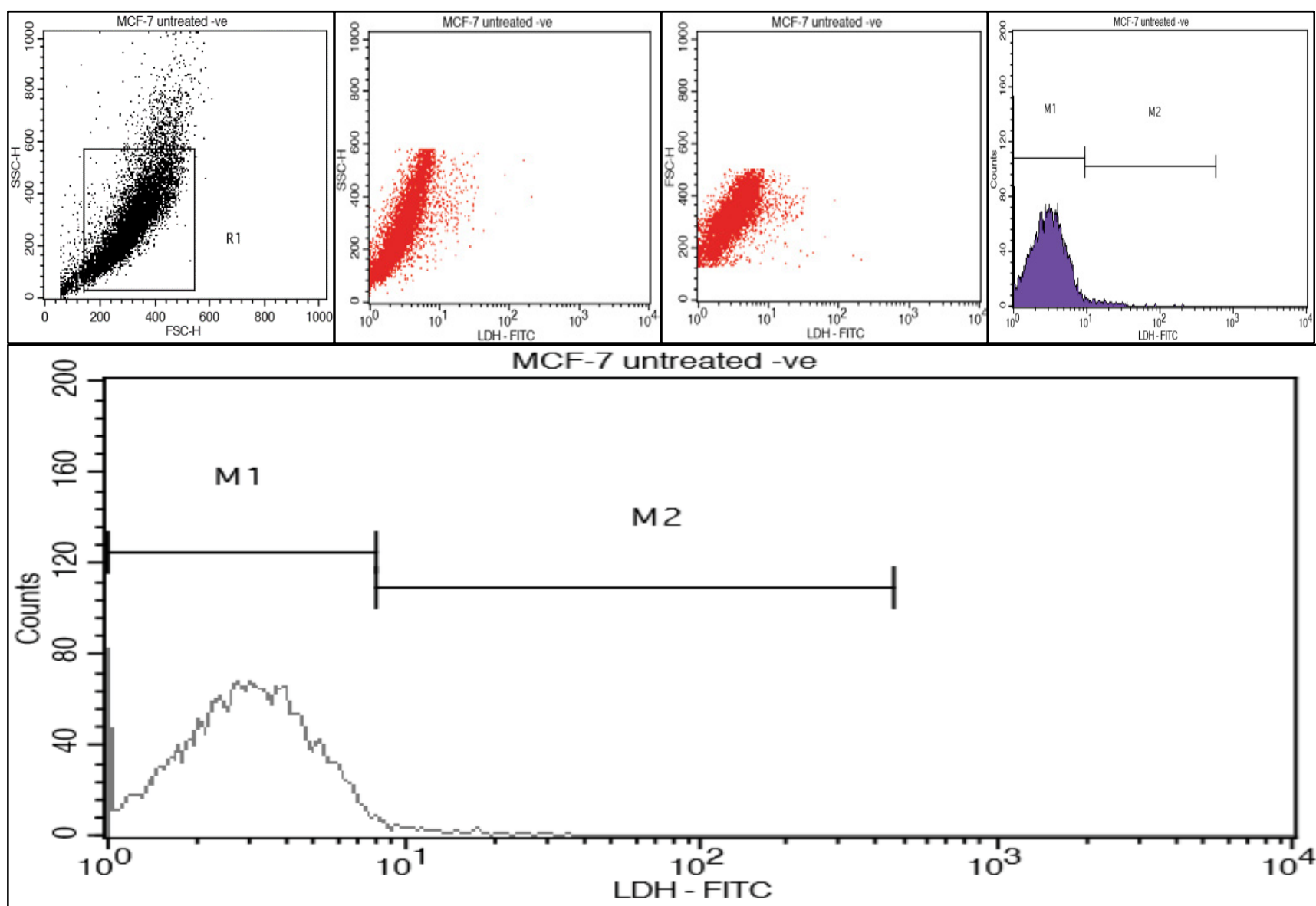

Histogram Statistics

File: MCF-7 untreated -ve

Sample ID: MCF-7 untreated -ve

Tube: Untitled

Acquisition Date: 24-Jun-15

Gated Events: 8872

X Parameter: LDH - FITC (Log)
Log Data Units: Linear Values

Patient ID:

Panel: Untitled Acquisition Tube List

Gate: G1

Total Events: 10000

\begin{tabular}{rrrrrrrrrr} 
Marker & Left, Right & Events & \% Gated & \% Total & Mean & Geo Mean & CV & Median & Peak Ch \\
\hline All & 1,9910 & 8868 & 100.00 & 88.68 & 3.58 & 3.04 & 107.25 & 3.05 & 1 \\
M1 & $1, \quad 8$ & 8639 & 97.42 & 86.39 & 3.25 & 2.93 & 45.47 & 3.00 & 1 \\
M2 & 8, 445 & 241 & 2.72 & 2.41 & 15.83 & 13.15 & 111.93 & 11.24 & 8
\end{tabular}

Figure 12: The Unstained LDH FITC negative cells were put in the M1 region (97.42\%). 


\section{Metformin}
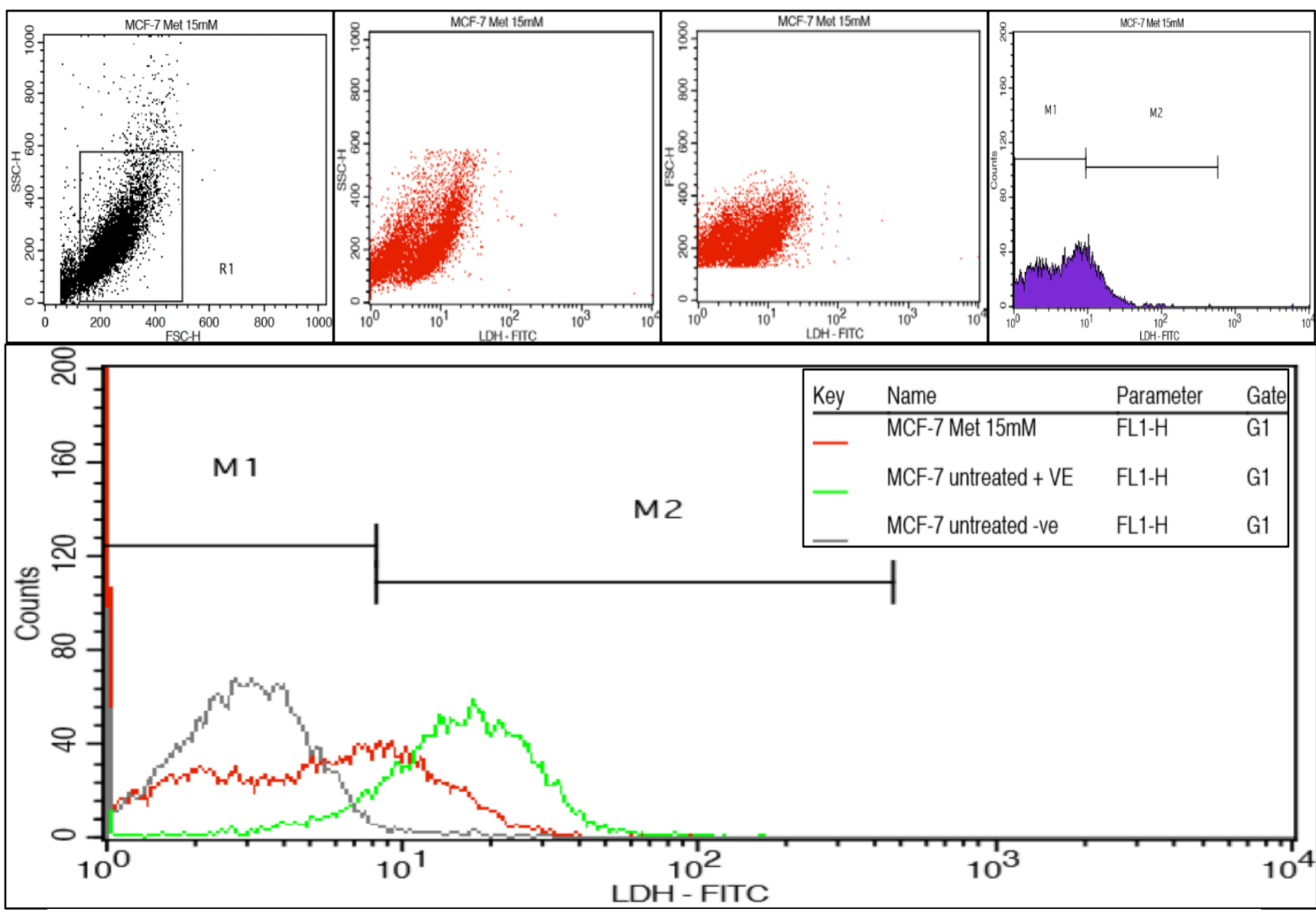

Histogram Statistics

File: MCF-7 Met 15mM

Sample ID: MCF-7 Met 15mM

Tube: Untitled

Acquisition Date: 24-Jun-15

Gated Events: 8689

X Parameter: LDH - FITC (Log)
Log Data Units: Linear Values

Patient ID:

Panel: Untitted Acquisition Tube List

Gate: G1

Total Events: 10000

\begin{tabular}{|c|c|c|c|c|c|c|c|c|c|}
\hline Marker & Left, Right & Events & $\%$ Gated & $\%$ Total & Mean & Geo Mean & CV & Median & Peak Ch \\
\hline$\overline{\text { All }}$ & 1,9910 & 8693 & 100.00 & 86.93 & 8.46 & $\overline{4.64}$ & 1437.30 & 5.05 & 1 \\
\hline M1 & & 6083 & 69.98 & 60.83 & 3.65 & 3.01 & 58.55 & 3.08 & 1 \\
\hline M2 & 8,445 & 2678 & 30.81 & 26.78 & 13.59 & 12.48 & 79.36 & 11.55 & 10 \\
\hline
\end{tabular}

Figure 13: Metformin treated cells showed a decrease in FITC fluorescence intensity and hence a decrease in LDH with more cells in the M1 region (69.98\%) than the $\mathrm{M} 2$ region $(30.82 \%)$. 


\section{Ethyl acetate extract}
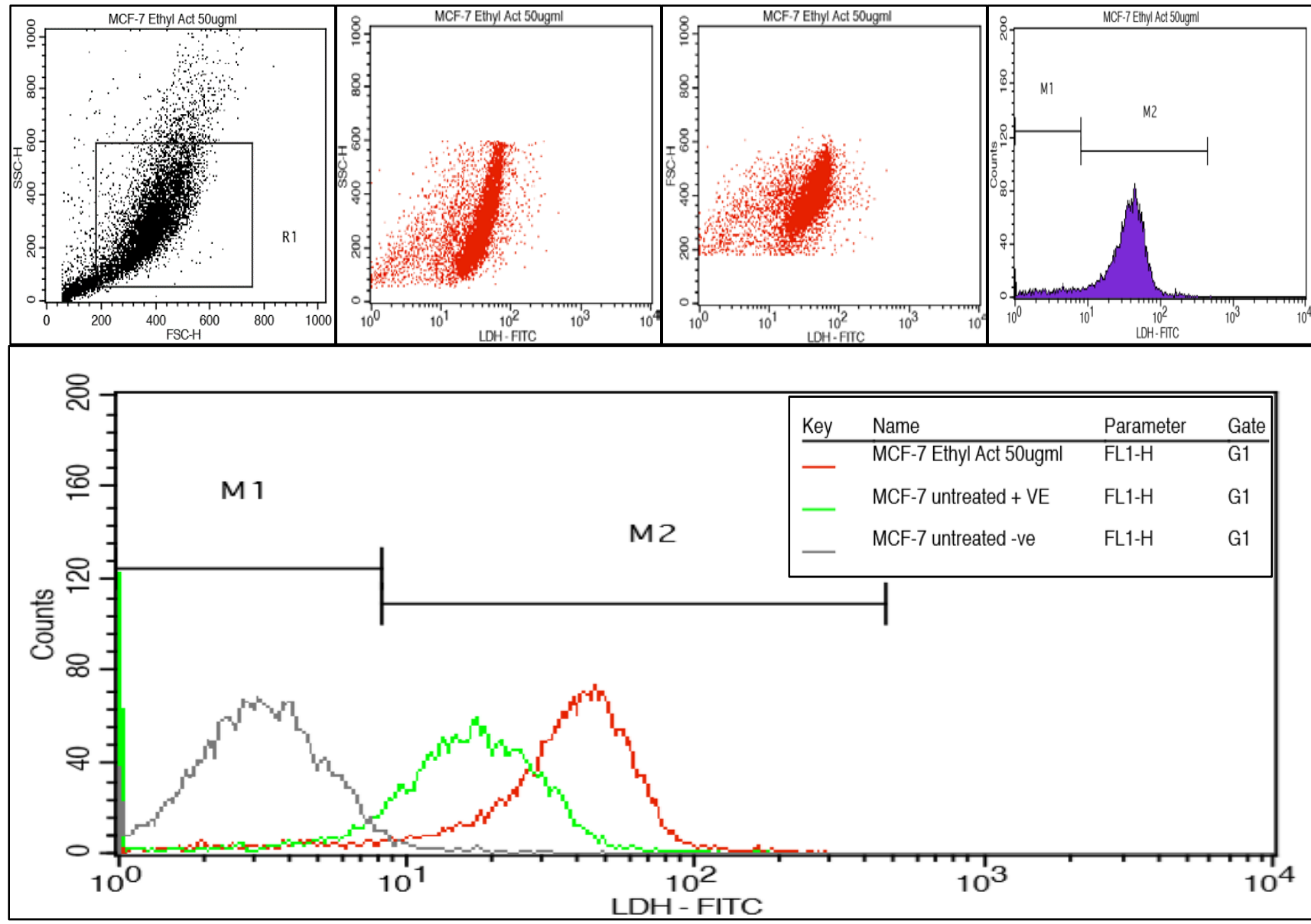

Histogram Statistics

File: MCF-7 Ethyl Act 50ugml

Sample ID: MCF-7 Ethyl Act 50ugml

Tube: Untitled

Acquisition Date: 30-Jun-15

Gated Events: 8015

X Parameter: LDH - FITC (Log)
Log Data Units: Linear Values

Patient ID:

Panel: Untitled Acquisition Tube List

Gate: G1

Total Events: 10000

\begin{tabular}{|c|c|c|c|c|c|c|c|c|c|}
\hline Marker & Left, Right & Events & $\%$ Gated & $\%$ Total & Mean & Geo Mean & CV & Median & Peak Ch \\
\hline All & 1,9910 & 7996 & 100.00 & 79.96 & 37.97 & 30.46 & 60.99 & 36.85 & $\overline{44}$ \\
\hline M1 & & 571 & 7.14 & 5.71 & 3.85 & 3.28 & 53.05 & 3.65 & \\
\hline M2 & 8,445 & 7430 & 92.92 & 74.30 & 40.51 & 36.10 & 52.66 & 38.20 & 44 \\
\hline
\end{tabular}

Figure 14: Ethyl acetate extract did not show any significant decrease in LDH. 


\section{Hexane extract}
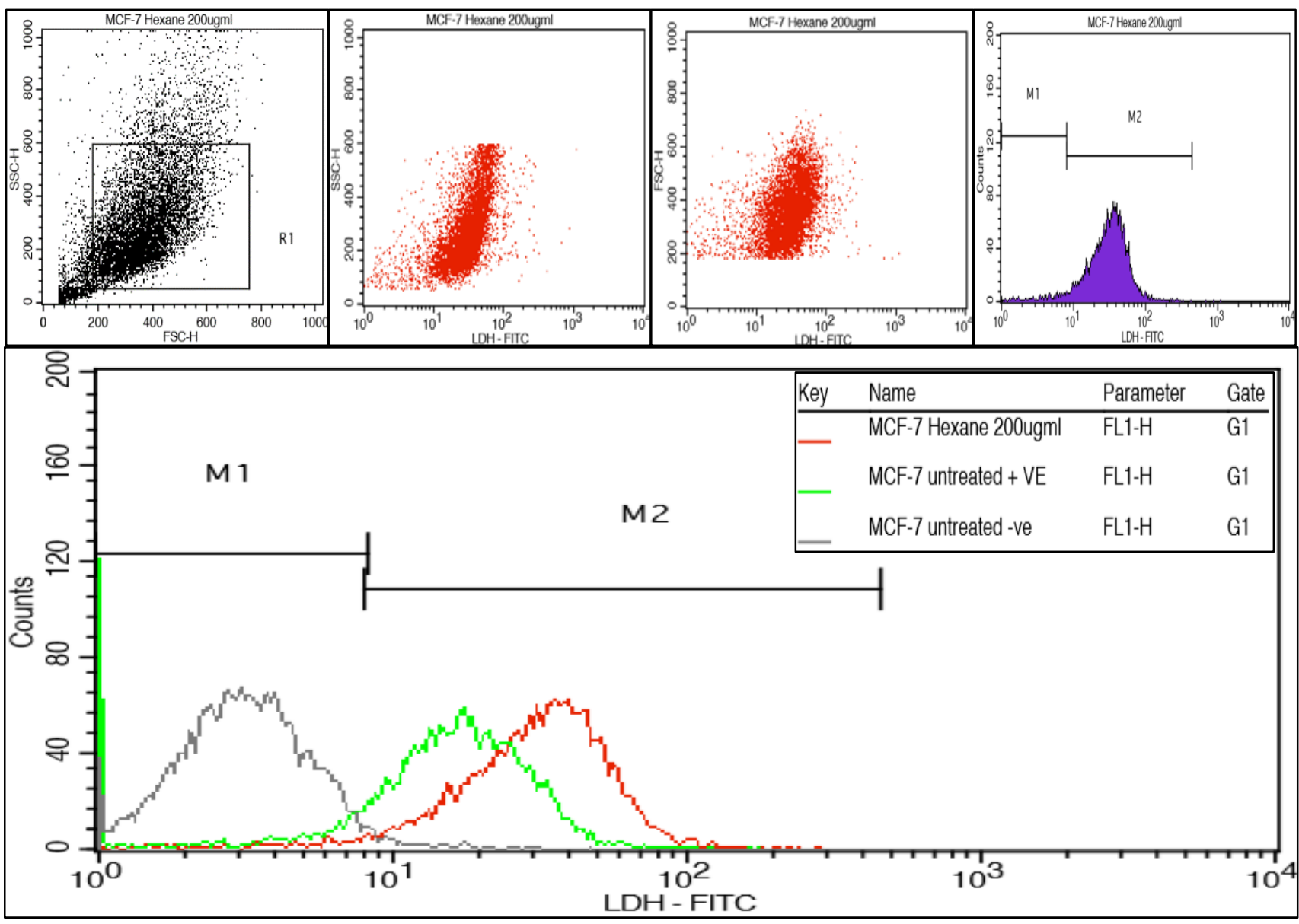

Histogram Statistics

File: MCF-7 Hexane 200ugml

Sample ID: MCF-7 Hexane 200ugml

Tube: Untitled

Acquisition Date: 30 -Jun-15

Gated Events: 7961

X Parameter: LDH - FITC (Log)
Log Data Units: Linear Values

Patient ID:

Panel: Untitled Acquisition Tube List

Gate: G1

Total Events: 10000

\begin{tabular}{|c|c|c|c|c|c|c|c|c|c|}
\hline Marker & Left, Right & Events & $\%$ Gated & $\%$ Total & Mean & Geo Mean & CV & Median & Peak Ch \\
\hline All & 1,9910 & 7951 & 100.00 & 79.51 & 34.73 & 28.83 & 78.91 & 31.62 & 35 \\
\hline M1 & 1,8 & 309 & 3.89 & 3.09 & 4.59 & 3.98 & 47.79 & 4.49 & 5 \\
\hline M2 & $8, \quad 445$ & 7651 & 96.23 & 76.51 & 35.58 & 31.13 & 60.17 & 32.49 & 35 \\
\hline
\end{tabular}

Figure 15: Hexane extract also did not show any significant decrease in LDH. 


\section{Chloroform extract}
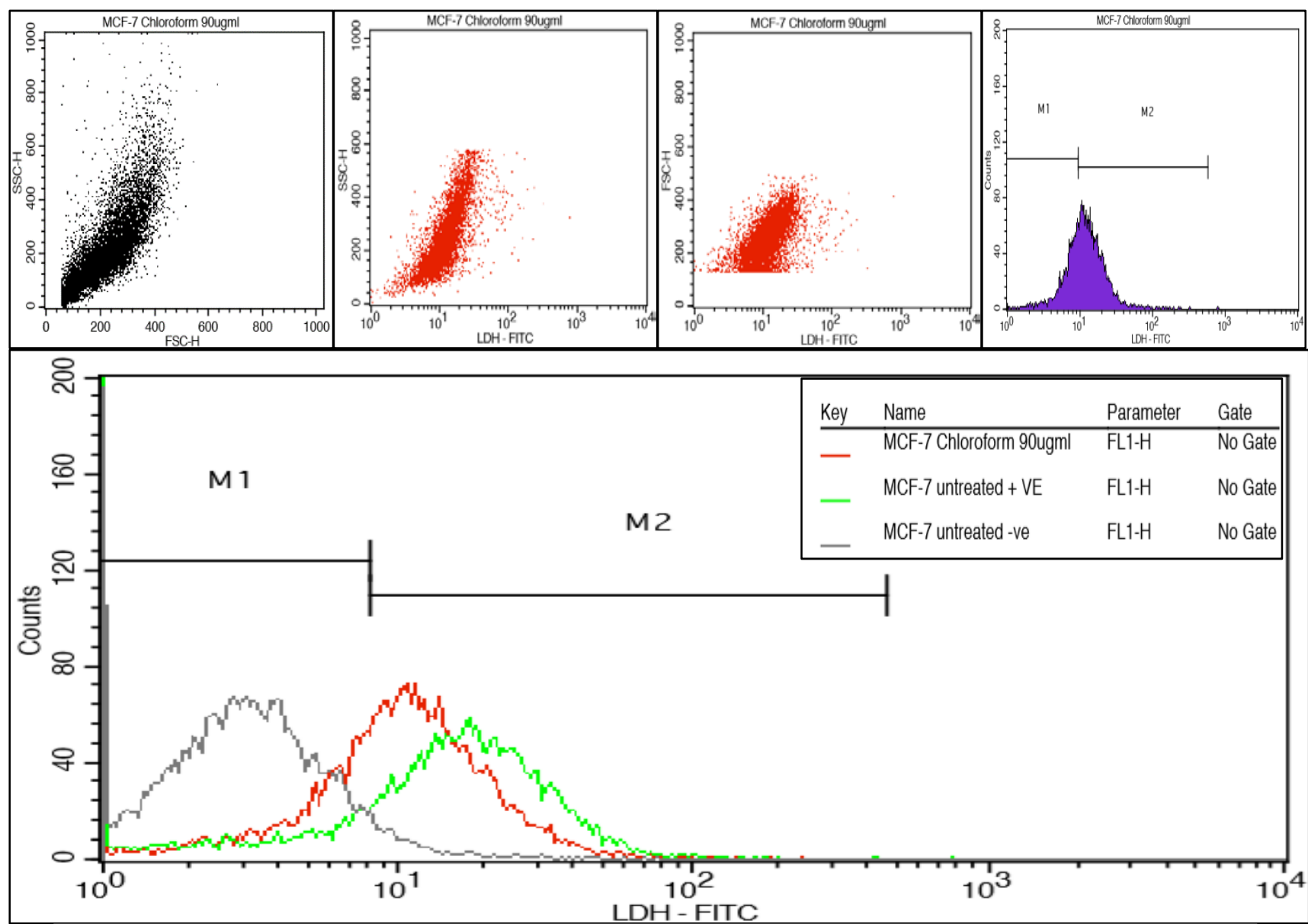

Histogram Statistics

File: MCF-7 Chloroform 90ugml Sample ID: MCF-7 Chloroform 90ugml

Tube: Untitled

Acquisition Date: 24-Jun-15

Gated Events: 10013

X Parameter: LDH - FITC (Log)
Log Data Units: Linear Values

Patient ID:

\section{Panel: Untitted Acquisition Tube List}

Gate: No Gate

Total Events: 10000

\begin{tabular}{|c|c|c|c|c|c|c|c|c|c|}
\hline Marker & Left, Right & Events & $\%$ Gated & $\%$ Total & Mean & Geo Mean & CV & Median & Peak Ch \\
\hline$\overline{\text { All }}$ & 1,9910 & 10000 & 100.00 & 100.00 & 14.88 & 10.01 & 809.33 & 10.37 & 10 \\
\hline M1 & 1,8 & 3304 & 3.04 & 33.04 & 5.23 & 4.68 & 39.10 & 5.62 & 1 \\
\hline M2 & 8,445 & 6774 & 67.74 & 67.74 & 16.55 & 14.42 & 88.26 & 13.10 & 10 \\
\hline
\end{tabular}

Figure 16: Chloroform extract treated cells showed a decrease in LDH with $33.04 \%$ cells in the M1 region and $67.74 \%$ cells in the $\mathrm{M} 2$ region 


\section{Ether extract}
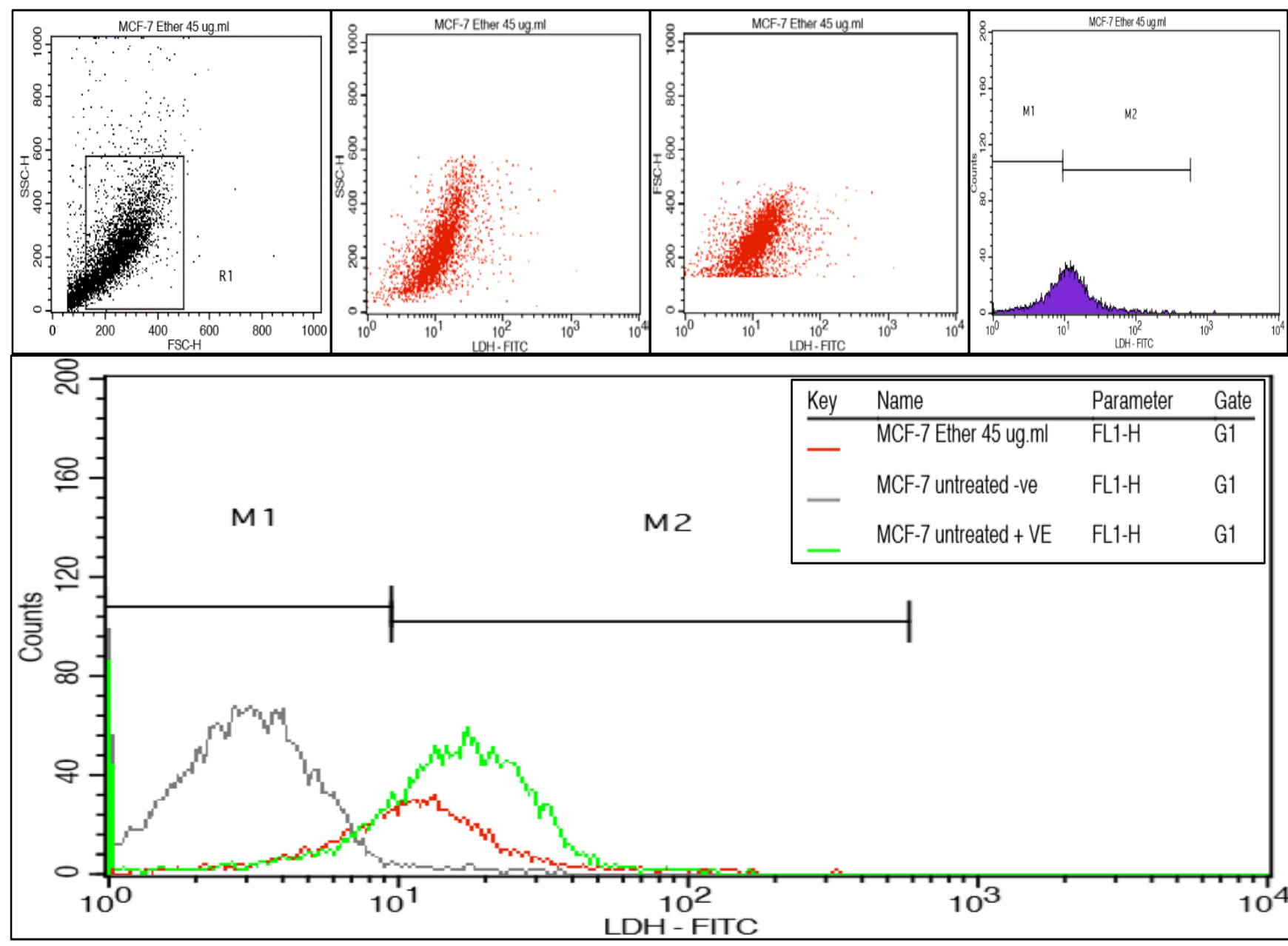

Histogram Statistics

File: MCF-7 Ether 45 ug.ml

Sample ID: MCF-7 Ether 45 ug.ml

Tube: Untitled

Acquisition Date: 24-Jun-15

Gated Events: 3868

X Parameter: LDH - FITC (Log)
Log Data Units: Linear Values

Patient ID:

Panel: Untitled Acquisition Tube List

Gate: G1

Total Events: 5040

\begin{tabular}{|c|c|c|c|c|c|c|c|c|c|}
\hline Marker & Left, Right & Events & $\%$ Gated & $\%$ Total & Mean & Geo Mean & CV & Median & Peak Ch \\
\hline All & 1,9910 & 3862 & 100.00 & 76.63 & 14.90 & 11.17 & 182.68 & 11.24 & 11 \\
\hline M1 & & 1430 & 37.03 & 28.37 & 6.36 & 5.89 & 33.38 & 6.67 & 8 \\
\hline M2 & $9, \quad 578$ & 2460 & 63.70 & 48.81 & 19.32 & 16.13 & 119.28 & 14.39 & 11 \\
\hline
\end{tabular}

Figure 17: Ether extract also showed a decrease in $\mathrm{LDH}$ with $37.03 \%$ cells in the $\mathrm{M} 1$ region and $63.70 \%$ cells in the $\mathrm{M} 2$ region 


\section{Benzene extract}
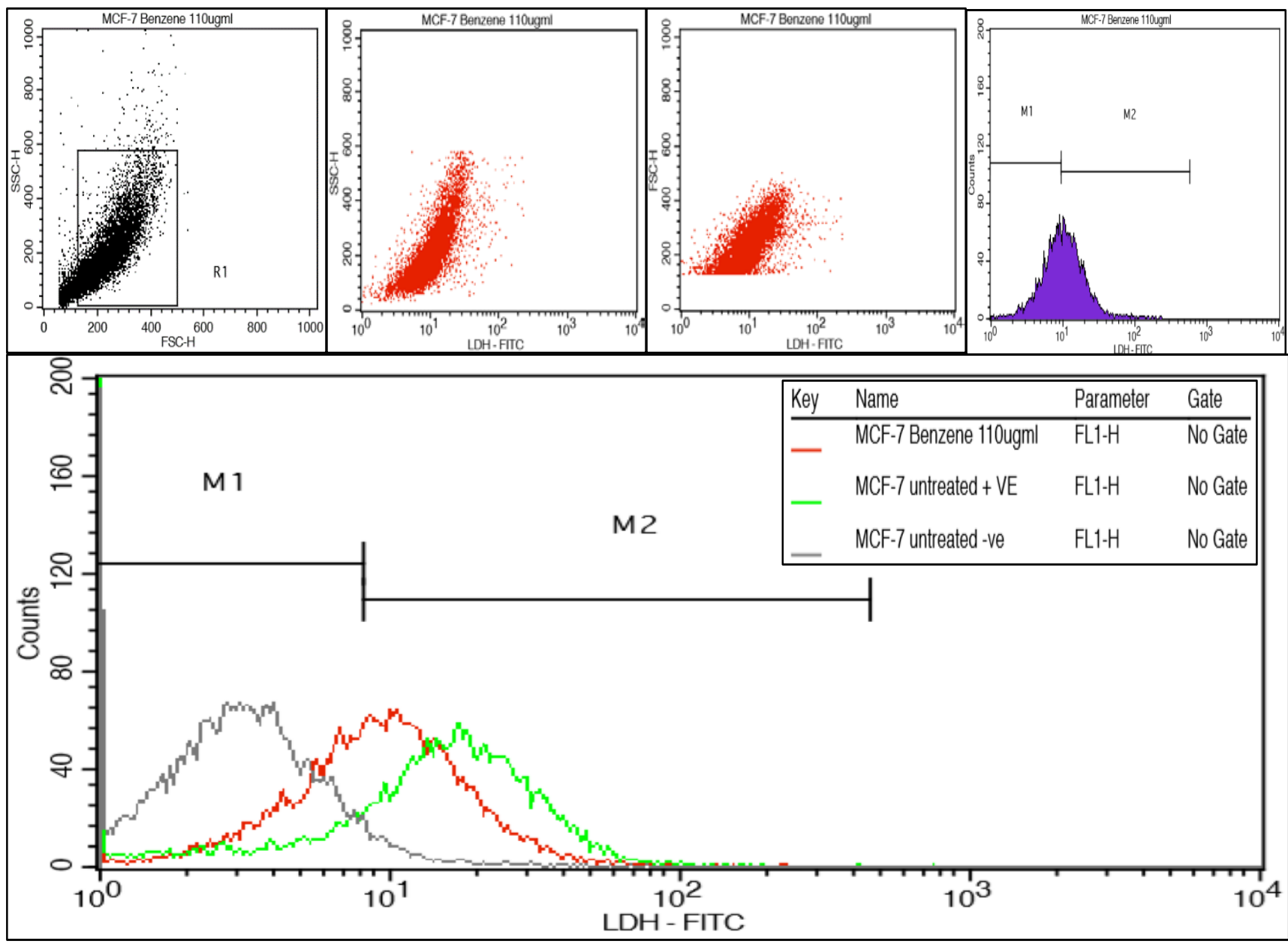

Histogram Statistics

File: MCF-7 Benzene 110ugml Sample ID: MCF-7 Benzene 110ugml Tube: Untitled

Acquisition Date: 24-Jun-15

Gated Events: 9998

X Parameter: LDH - FITC (Log)
Log Data Units: Linear Values

Patient ID:

Panel: UntittedAcquisition Tube List

Gate: No Gate

Total Events: 10000

\begin{tabular}{rrrrrrrrrr} 
Marker & Left, Right & Events & \% Gated & \% Total & Mean & Geo Mean & CV & Median & Peak Ch \\
\hline All & 1,9910 & 10000 & 100.00 & 100.00 & 14.88 & 9.06 & 1094.26 & 9.31 & 8 \\
M1 & $1, \quad 8$ & 4158 & 41.58 & 41.58 & 5.22 & 4.78 & 36.14 & 5.47 & 6 \\
M2 & 8, 445 & 5949 & 59.49 & 59.49 & 16.12 & 14.08 & 87.69 & 12.86 & 8
\end{tabular}

Figure 18: Benezene extract treated cells showed a decrease in LDH with $41.58 \%$ cells in the M1 region and $59.49 \%$ cells in the M2 region 
Citation: Mohammed YHE (2016) In-vitro Anti-Cancer Activity of Extracts Dracaen Cinnabari Balf. F Resin from Socotra Island in Yemen Republic. Biochem Anal Biochem 5: 296. doi: 10.4172/2161-1009.1000296

Table 6, Figures 9 and 10.

Figures 11-18

\section{Discussion and Conclusion}

Sample collected in this study was selected to include the plant resin that have suggested bioactivity on the basis of their non-reported traditional usage as medicines. The plant resin used on traditional treatments for various disease as fever, tonsillitis, cough, dysentery, diarrhea, skin disease. The major aim of this study was to identify potential anticancer extracts that were affective not by feature of high concentration alone, relatively by specific activity demonstrated even at low doses. In order to achieve this aim, the maximum concentration ( $\mu \mathrm{g} / \mathrm{ml})$ used in the study was $100 \mu \mathrm{g} / \mathrm{ml}$ as above results as the criteria for identifying plant resin with potent activity within range. Plants with less than $50 \%$ inhibitory activity within the test range were excluded from father screening. The concentration that causes $50 \%$ inhibition of cancer cells by the crude extract of the dragon blood resin displayed. Screening of Ether and Ethyl acetate of dragon cinnabari Balf. F showed the cytotoxicity studies revealed that the half minimum inhibitory concentration $\left(\mathrm{IC}_{50}\right.$ ) for the Ether and Ethyl acetate extract are $48.117,50.692 \mu \mathrm{g} / \mathrm{ml}$ respectively, which resulted in moderate anticancer activities against MCF-7 cell lines, while the benzene extract showed $\mathrm{IC}_{50} 115.218 \mu \mathrm{g} / \mathrm{ml}$ which is less than ether and ethyl acetate extract extract with IC $_{50}$ extract against MCF-7 cell lines, as well as the hexane extract revealed that the $\mathrm{IC}_{50}$ is $93.1136 \mu \mathrm{g} / \mathrm{ml}$ which is the least extract. The inhibitory properties of these extracts are compared with standard Metformin for MCF-7 cell line. The Percentage cancer cell inhibition profiles were found to be concentration dependent. Based on the cytotoxicity studies against MCF-7 cell lines the Ether and Ethyl acetate extracts could be used as potential source for anticancer drugs. On the other hand, Benzene, Chloroform and Ether extract treated cells showed a significant decrease in LDH FITC fluorescence intensity due to LDH leakage which indicates a necrotic cell death mechanism. While, Ethyl acetate and Hexane extract treated cells showed high LDH FITC fluorescence intensity which indicates an intact cell membrane and a possible apoptotic cell death mechanism.

\section{Acknowledgement}

Yasser Hussein Issa Mohammed gratefully acknowledges the financial support provided by the University of Hajja, Yemen.

\section{References}

1. Mallikharjuna P, Rajanna L, Seetharam Y, Sharanabasappa G (2007) Phytochemical studies of Strychnos potatorum L.f. A medicinal plant. E-J Chem 4: 510-518.

2. Saad B, Azaizeh H, Said O (2005) Tradition and perspectives of Arab herbal medicine: a review. Evid Based Complement Alternat Med 2: 475-479.

3. Anjana S, Verma R, Ramteke P (2009) Antibacterial activity of some medicinal plants used by Tribals against UTI causing pathogens. W App Sci J 7: $332-$ 339.

4. Mothana R, Mentel R, Reiss C, Lindequist U (2006) Phytochemical screening and antiviral activity of some medicinal plants from the island Socotra. Phytother Res 20: 298-302.

5. Abu-Taleb AY, Fahad Ahmed MA, Tukaram AK, Rafik US (2013) In vitro evaluation of antimicrobial and antioxidant activity of Dragon's blood tree (Dracaena cinnabari Balf.f.) of Socotra Island (Yemen). Journal of Coastal Life Medicine 1: 123-129.

6. Mohammed M, Helmut R, Ueve H, Gunter A (1995) Cinnabaron, ABiflavonoid from Dragon's Blood of Dracaena Cinnabari, Institute of plant. Phytochemistry 38: $751-753$.

7. Masaoud M, Himmelrich U, Ripperger H, Adam G (1995) New bioflavonoid from Dracaena Cinnabari. Plant Medica 61: 341-344.

8. Trease GE, Evans WC (1989) Pharmacognosy, London: (13thedn), Bailliere Tindall, 176-180.

9. Pandey G, Madhuri S (2006) Medicinal plants: better remedy for neoplasm Indian Drugs 43: 869-874.

10. Mosmann T (1983) Rapid colorimetric assay for cellular growth and survival: Application to proliferation and cytotoxicity assays. J Immunol Method 65: 5563.

11. Lahouel M, Viotte G, Sumereau E, Morin JP, Fillastre JP (1987) Haematotoxicity of doxorubicin and 1-(2-chloroethyl)-3- cyclohexyl 1 -nitroso urea (CCNU) and of their association in rats. Drugs under Experimental and Clinic Res 13: 593599

12. Liu Y, Wang MW (2008) Botanical drugs: Challenges and opportunities: Contribution to Linnaeus memorial symposium 2007. Life Science 82: 445-449.

13. Kasabana S, Hemini S (1998) Medicinal herb index in Indonesia, Bogor, Indonesia. P.T.Eisai, Indonesia..

14. Cragg GM, Newman DJ (2005) Plants as a source of anti-cancer agents. J. Ethnopharmacol 100: 72-79.

15. Miller AG, Morris M (1988) Plants of Dhofar-the southern region of Oman traditional, economic and medicinal uses .Office of the adviser on the Environment, Diwan of Royal Court, Sultanat of Oman.

16. Balamurugan K, Sakthidevi G, Mohan VR (2012) Anti-inflammatory activity of whole plant of Melastoma malabathricum L. (Melastomataceae). Int J Res Ayu Pharmacy 3: 801-802.

17. Nishanthini A, Balamurugan K, Mohan VR (2012) Evaluation of hepatoprotective and antioxidant activity of Melastoma malabathricum L. Leaf- $\mathrm{CCl} 4$ induced hepatotoxicity in rats. Int J Cur Pharmaceu Res 5: 38-41.

18. Tsay HS, Agrawal DC (2005) Tissue culture technology of chinese medicinal plant resources in Taiwan and their Sustainable Utilization. Int J App Sci Eng 3: $215-223$.

19. Ahmed A, Mosa'd A, Yahia C, Katim A (2012) Anti-inflammatory and analgestic effect of ethanol extract of dracaena cinnabari balf, as endemic plant in Yemen. International Journal of Pharma and Bio Sciences 3: 96-106.

20. Ranganath VL, Avin BR, Thirusangu P, Prashanth T, Prabhakar BT, et al (2013) Synthesis, angio-preventive activity, and in vivo tumor inhibition of novel benzophenone-benzimidazole analogs. Life Sci 93: 904-911.

21. (2005) Glucose uptake cell-based assay kit: Cayman Chemical Catalog no 600470

22. Kantoff $P$ (2005) Recent progress in management of advanced prostate cancer, Oncology (Williston) 19: 631-636.

23. Jemal A, Bray F, Center MM, Ferlay J, Ward E, et al. (2011) Global cancer statistics, CA Cancer J Clin 6: 69-90.

24. Shi L, Hu R, Wei Y, Liang Y, Yang Z, et al. (2012) Anthranilic acid-based diamides derivatives incorporating aryl-isoxazoline pharmacophore as potential anticancer agents: Design, synthesis and biological evaluation. Eur J Med Chem 54: 549-556.

25. Lorusso G, Rüegg C (2008) The tumor microenvironment and its contribution to tumor evolution toward metastasis, Histochem. Cell Biol 130: 1091-1103. 